\title{
PROBLEM DIALOG ANTARIMAN: Membangun Keberagamaan Inklusif
}

Oleh: Zuly'Qodir*

Abstract

This article describes actual problems on religious dialogue, in actual Indonesia. Several problems in interfaith dialogue, such as contexts of as textual-doctrine, human dialogue, community segmentation in Muslim and Christian, on five years era, praxis and theoretic theology dichotomy; religious prejudice on Muslim and Christian, and then minimum women activities on interfaith dialogue. But, these problems can create encounter dialogue and human dialogue intensively. For alternative solution the problems is religious inclusive.

وصف الكاتب في هذا البحث ظاهرة الموار بين الأديان في إندونيسيا وعدة مشاكل التي تنتجها

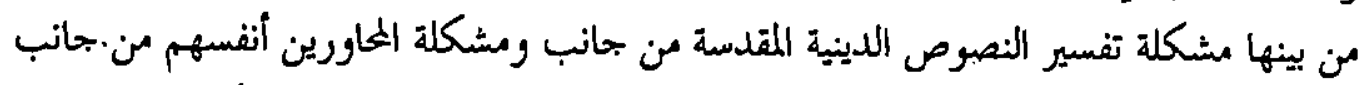

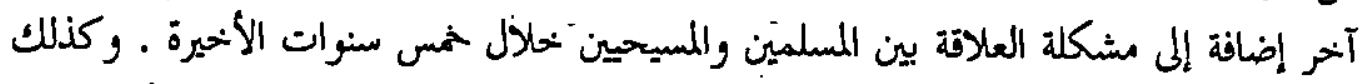
مشكلة انفصال بين اللالاموت والواقع وموقف المتدينين بحاه بعضهم بعضا ـ ـ والقضية الأخرى التي

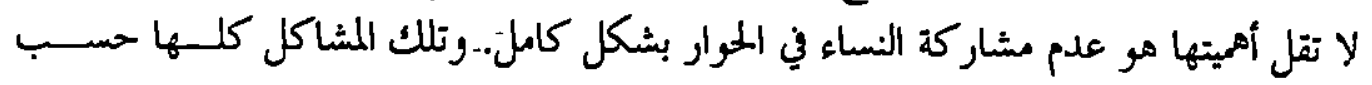

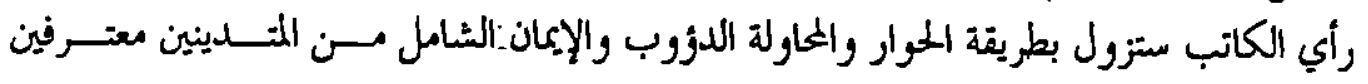
ومحترمين بعضهم بعضا .

Kata Kunci: Agama, Dialog, Inklusif

* Mahasiswa S3 Sosiologi Universitas Gadjah Mada Yogyakarta 


\section{A. Pendahuluan}

D roblem klasik dalam hal hubungan antaragama, utamanya Kristen-Islam serta agamaagama tradisional lainnya adalah problem teologis dan filosofis yang sampai sekarang tidak juga dapat terselesaikan dengan sempurna. Dia merupakan problem mensejarah yang membutuhkan pemikiran secara intens dan mendasar. Problem ini merupakan masalah yang terdapat dalam diri agama-agama "samawi" yang disebabkan karena adanya otoritarianisme dan penolakan akan adanya pertanyaan-pertanyaan yang populer dalam menggugat "kemapanan agama-agama" di muka bumi. Oleh sebab itu, sebagai salah satu jalan keluar dari problem klasik ini haruslah ada theology of encounter yang sifatnya memperbarui cara pandang dan sikap dalam beragama. ${ }^{1}$

Pertanyaan kemudian dapat diajukan disini, mengapa problem utama muncul pada wilayah teologi dan filosofis, bukan pada wilayah yang lainnya? Disinilah kita kemudian harus lari kebelakang untuk merunut tradisi-tradisi agama-agama besar (Abrahamic Religions) yang telah mensejarah. Perang Salib atau Perang Sabil antara Yristen-Islam tahun 1095, yang dikumandangkan Paus Urban II, yang menyerukan ekspedisi yang kemudian dikenal Perang Salib Pertama, sebagaimana survei Karen Armstrong menunjukkan dari sanalah akar permusuhan Kristen-Islam mulai ditabuh. ${ }^{2}$

Sebelum secara panjang lebar dibahas problem-problem dialog antariman perlu ditekankan dahulu, bahwa tulisan ini tidak bertujuan untuk membahas persoalan-persoalan yang ada dalam setiap agama besar (Abrahamic Religions), apalagi agama-gama yang di luar tradisi Ibrahimi. Tulisan ini hanyalah bahasan "kecil" atas problem antariman yang sering terjadi dalam rumpun agama Ibrahim Kristen-Islam. Oleh sebab itu, perlu dipahami agama-agama di luar ini tidak menjadi fokus pembahasan. Bahkan, mungkin sekali tidak dibahas, sekalipun dapat saja masalah-masalah yang terdapat dalam Kristen-Islam menjadi masalah agama-agama lain.

Sảat ini kita akan menuju teologi, yang disebut teologi dialog antariman. Mengapa, teologi ini penting? Sebab selama ini kita lebih sering berpikir tentang "teologi kita, tanpa memikirkan teologi orang lain."Padahal, di sekeliling kita sangat mungkin terdapat orangorang yang berbeda teologi dan keyakinannya tentang apa yang kita yakini, namun nyata adanya. Pertanyaannya, bagaimana kita akan menjalin hubungan dengan orang-orang yang dianggap berbeda iman dan teologinya. Adakah sistem teologi yang memungkinkan tentang ini, padahal seringkali orang yang berbeda dengan kita dalam hal keimanan sudah dianggap salah, kecuali orang yang seiman dengan kita.

Sungguh-sungguh bukan persoalan mudah untuk membedah paham teologi yang telah mengakar sebagai sebuah sistem keyakinan umat beragama. Jelas sistem teologi tidak semuanya salah, tetapi jika pada akhirnya antara penganut paham teologi yang

'Eric J. Sharpe, "The Goais of Inter-Religious Dialogue," dalam John Hick (Ed), 1974, Truth and Dialogue, New York: Sheldon Press, hal. 77

${ }^{2}$ Karen Armstrong, 2003, Perang Suci, Jakarta: Serambi, hal. 9 
satu dengan lainnya senantiasa "bermusuhan" dan saling mengintip, akhirnya membuat orang beragama seakan-akan harus senantiasa bermusuhan dan berpecah belah. Agama kemudian tidak lagi menjadi integrating factors, tetapi menjadi dis-integrating factors. Ini yang sesungguhnya berbahaya jika terus berkembang di tengah masyarakat religius.

Tradisi keberagamaan yang mengarah pada adanya keterbukaan teologi sebenarnya terdapat pada tradisi spiritualitas yang memungkinkan adanya titik temu universil agama-agama. Tradisi semacam ini bisa kita temukan dalam tradisi religiusitas para sufi agung, atau tradisi para mistikus semacam Ibn Arabi, Al-Halaj, Hamzah Fansuri bahkan Syekh Siti Jenar. Pengalaman-pengalaman keberagamaan mereka telah membantu kita memahami perbedaan religiusitas yang diyakini sepanjang hayat umat manusia, bahkan tradisi mistikus membuat kita menjadi manusia bijaksana dalam beragama. Dua tradisi keagamaan saling kontraproduktif, sehingga nyaris tidak bisa didamaikan, sekalipun sebenarnya tangga menuju “jalan spiritualitas” adalah menapaki tangga eksoterik.

Mengingat kesulitan semacam itu, dalam tulisan ini saya ingin mengemukakan beberapa problem dialog antariman, dimana saya sebagai seorang muslim yang berada dalam ruang penuh dengan gejala sosial keagamaan, politik, dan budaya sehinggga sangat mungkin mempengaruhi cara beragama seseorang. Dalam kondisi seperti inilah, sebenarnya keimanan seseorang benar-benar diuji oleh fenomena dan fakta-fakta sosial. Bagaimana saya sebagai muslim mampu bersikap dan berpijak pada ajaran-ajaran Islam untuk tetap mampu menempatkan diri tanpa terjebak pada pertarungan ideologi agamaagama. Sebab, agama-agama menjadi ideologi ketika agama-agama berkesempatan melakukan ekspansi dan merasa perlu menundukkan agama lain yang dianggap tidak sesuai dengan kehendak Tuhan. Agama semacam ini jauh lebih mengerikan ketimbang persebaran ideologi-ideologi dunia yang dituduh kaum agamawan berbahaya, seper $i$ sosialisme-komunisme dan kapitalisme.

Agama-agama hemat saya tidak bisa melepaskan dirinya pada ideologi yang dibawanya, lebih-lebih agama-agama rumpun Abraham, yang menamakan diri sebagai Abrahamic Religions (Yahudi, Kristen dan Islam). Ketiga rumpun agama ini memiliki ideologi sendiri yang kita sebut sebagai missionary ideology yang tak jarang membawa akibat bentrokan-bentrokan di antara ketiganya, juga dengan agama-agama di luar tiga rumpun agama semitik ini. ${ }^{3}$

Ideologi misionaris dalam tiga rumpun agama Abraham ini yang selama bertahuntahun terus berkembang dalam wacana dan realitas keagamaan kita, baik pada tataran dunia maupun tataran nasional, bahkan lokal. Dalam tataran dunia telah kita saksikan betapa perang yang melibatkan kaum Kristen dengan Yahudi menelan ribuan umat manusia terbunuh, barangkali sia-sia, sekalipun tampak oleh kaum beragama sebagai "mati di

${ }^{3}$ Karen Armstrong, 2001, Sejarah Tuhan, Bandung: Mizan, hal. 72-119 
jalan Tuhan" karena dianggap melakukan perang suci. Sebuah peperangan membela agama Tuhan.

Sementara dalam tataran nasional-lokal kita dapat melihat betapa susahnya kaum beragama Konghucu, agama lokal seperti Kaharingan, Samin dan sejenisnya "dikejarkejar" oleh tiga agama besar ini untuk dipertobatkan. Tiga agama besar merasa bertanggung jawab untuk mengimankan orang Konghucu, Kaharingan, Samin dan sejenisnya. Pengejaran atas mereka terutama dilakukan ketika rezim Orde Baru, yang hanya mengakui dan sekaligus memaksakan pada warganya hanya lima agama resmi sebagai agama negara. Keimanan diukur dengan kehendak rezim kekuasaan, bukan pada ekspresi keyakinan seseorang yang merasa mendapatkan insight karena kepercayaannya itu. Keimanan zaman rezim Orde Baru tidak lebih dari sebuah formalisme keagamaan yang sungguh-sungguh sangat dangkal, dan menyebalkan. Kegiatan pertobatan dan pengimanan seseorang menjadi kegiatan rutin agama-agama besar dengan dukungan rezim berkuasa. Di sinilah sesungguhnya sebuah idelogi misionaris berjalan amat sempurna, sebab di luar agama resmi pasti mendapat teror.

Akibat paling jelas dari adanya ideologi misionaris, sekalipun paling kentara antara Kristen-Islam, dimana kedua agama ini sama-sama agresif dalam melakukan aktivitas misinya. Kedua agama ini seakan-akan dapat dibilang sebagai agama yang paling merasa bertanggung jawab atas keberagamaan umat manusia, sehingga tidak bisa melihat umat manusia untuk tidak Kristen atau Islam. Kedua agama ini sama-sama merasa paling berhak membuat umat manusia beriman kepada Tuhan, sekalipun dalam versinya.

Tuhan dalam versi Kristen dan Islam menjadi standar yang tidak boleh ada pemahaman Tuhan di luarnya. Akibatnya,jika ada orang yang tidak atau belum Kristen atau Islam maka diusahakan agar Kristen atau Islam. Kristen dan Islam-lah yang menawarkan keselamatan, bukan di luar agama ini. Keselamatan dalam Kristen dan Islam merupakan keselamatan mutlak yang tidak bisa ditawar-tawar, oleh sebab itu jika umat manusia tidak mau mengikutinya (dakwah/misinya) maka boleh diperangi dengan kekerasan. Jalan kekerasan, sekali lagi demikian tampak ketika rezim Orde Baru berada pada puncaknya untuk mengontrol seluruh aktivitas keberagamaan masyarakat. Masyarakat tidak lebih dari kelinci percobaan rezim.

Dari sanalah kemudian muncul term-term tentang kaum beriman, kufr, dosa besar, dan sorga, neraka dan sebagainya yang sebenarnya lebih banyak ditujukan kepada mereka yang tidak atau belum Kristen atau Islam. Inilah persoalan yang menurut saya merupakan hegemoni prinsip ketuhanan dalam agama-agama Abraham (Semitik), yang sama sekali tidakmengakui adanya pluralitas agama-agama dalam masyarakat, seperti Budha, Hindu, Sikh, dan sebagainya. Agama karena itu dalam "kacamata" Abrahamic Religions adalah yang berprinsip keesaan Tuhan, bukan berprinsip tritunggal, atau sejenisnya. Dalam tradisi Abrahamic Religions, memang tidak mengakomodir tradisi-tradisi di luar tiga agama besar, sehingga bisa dikatakan bahwa ini sebenarnya hegemoni tiga agama Abraham. 
Dalam kerangka seperti itulah, saya akan memberikan penjelasan pada tulisan ini, berkaitan dengan problem-problem yang saya temukan di lapangan ketika melakukan aktivitas dialog antariman. Islam dan agama-agama lainnya dalam tulisan ini saya tempatkan sebagai realitas sosial yang lahir bukan tanpa peristiwa, tanpa sebab, sehingga jelas bahwa Islam dan agama-agama lahir tidak vacum atas fenomena sosial yang mengirinya. Oleh karena, Islam khususnya lahir tidak vacum, maka memahami Islam harus mengalami revisi-revisi terutama dalam hal memahami kitab sucinya, baik dalam al-Qur'an maupun hadits-hadits yang dianggap mutawatir.

Saya merasa jika Islam tidak direvisi pemahamannya atas kitab suci, maka bukan tidak mungkin Islam hanya tinggal nama, bahkan memfosil, yang diberhalakan, dan diagung-agungkan karena "berhala Islam" yang dipikul kemana-mana. Ini jelas tidak layak dialamatkan kepada sebuah agama yang lahir untuk transformasi. Di sinilah perlunya rethinking atas keberagamaan dan keimanan kita selama ini untuk menuju keberagamaan dan keimanan yang baru, yang lebih apresiatif terhadap perbedaan teologi dan keyakinan.

\section{B. Sekilas Perjalanan Dialog Antariman}

Ketika awal mula banyak aktivitas kegiatan dialog antariman, sungguh bermacammacam tuduhan dialamatkan pada mereka yang mengerjakan. Sebagai sebuah kegiatan yang bisa dibilang "melawan kebiasaan" kaum beragama, dialog antariman sering mendapatkan kecaman, hujatan bahkan cemooh. Bahwa dialog antariman dituduh tidak lebih dari keberagamaan yang berusaha melakukan sinkretisasi antara agama dengan budaya, dan percampuran agama-agama. Dialog antariman seakan-akan menjadi aib kaum beragama, sebab dianggap hanya akan merapuhkan keberimanan seseorang akan agama yang telah dianut dan diyakini.

Ketakutan akan dialog antariman semacam ini bisa dipahami, sebab telah sekian lama keberagamaan rakyat benar-benar telah mengalami regimintasi, sehingga apa yang dianggap benar adalah apa yang sesuai dengan kehendak regim politik. Sementara yang tidak sesuai dengan kehendak regim, dalam beragama pun bisa menjadi tidak sah. Beragama menjadikan seseorang masuk penjara, atau masuk tangsi militer. Pengalamanpengalaman beberapa peristiwa yang menimpa orang-orang seperti Warsidi, Haorkoneng, dan orang Dayak Kaharingan bisa menjadi bukti betapa agama menjadi bagian dari regim politik. Beragama bukan dalam rangka menumbuhkan dan menyebarkan kedamaian berdasarkan nilai-nilai spiritual, moralitas tetapi menjadi bagian dari strategi rezim politik tertentu untuk mendukung proyek kekuasaan. Dialog antariman akhirnya menjadi eksklusif-elitis.

Dialog antariman di Indonesia sebenarnya digagas oleh mantan Menteri Agama A. MuktiAli kira-kira tahun 1980-an, sehingga jasa beliau dalam memberikan kebijakan untuk membuka Fakultas Ushuluddin Jurusan Perbandingan Agama di IAIN Sunan Kalijaga Yogyakarta, merupakan sebuah terobosan besar dari seorang akademisi- 
intelektual sekaligus praktisi birokrasi. MuktiAli bagaimana pun telah meletakkan "tapaktapak publik" bagi aktivitas dialog antariman yang lebih jujur, setara dan "membumi". MuktiAli sebab itu bisa dikatakan sebagai tokoh terdepan dalam proyek besar hubungan antaragama. Siapa saja yang menyebut aktivitas dialog antariman di Indonesia, harus menyebut nama Mukti Ali sebagai bagian tak terpisahkan dari proyek raksasa yang memiliki nilai strategis bagi kemajuan tumbuhnya mutual truts di antara penganut agama.

Sebagai sebuah aktivitas yang baru dirintis tahun 1980-an, bisa dipahami jika dialog antariman masih dianggap sebagai aktivitas eksklusif, dalam arti baru berlaku di lingkaran elite agama, belum pada tataran grass root, sekalipun memang jika ditelusuri lebih jauh, tataran grass root tidak banyak masalah hubungan antaragama, ketimbang tataran lingkaran elit. Sebab itulah, aktivitas dialog antariman terjadi di jajaran birokrasi pemerintahan, kalangan perguruan tingggi, dan aktivis lembaga swadaya masyarakat (LSM). Namun, yang sebenarnya ironis adalah bahwa aktivitas dialog antariman yang digagas Mukti Ali pada akhirnya tidak lebih sebagai aktivitas proyek negara, khususnya Departemen Agama (Depag). Tanpa kucuran duit dari Depag maka aktivitas dialog antariman (lebih tepatnya seri monolog) tokoh-tokoh agama yang digelar di hotel-hotel berbintang dengan biaya ratusan juta rupiah, tidak pernah menyentuh masalah riil masyarakat agama.

Di situlah problem dialog antariman menjadi semakin serius. Antartokoh agama peserta seri monolog bukan saling duduk bersama membahas masalah masyarakatnya, tetapi mempertontonkan kehebatan-kelebihan agamanya kepada tokoh agama yang lain. Sungguh sebuah pertunjukkan "sandiwara antartokoh agama" dengan biaya sangat mahal yang lebih memperkuat tumbuhnya bibit-bibit sentimen dan semangat parokialisme antaragama. Upaya untuk saling memahami, menghargai perbedaan ritual dan doktrin agama-agama sama sekali jauh dari keinginan Mukti Ali selaku pencetus gagasan dialog antariman.

Namun demikian, Mukti Ali dalam hal ini tidak bisa dipersalahkan, sebab Mukti Ali sebenarnya telah membuka ruang bagi publik agama-agama untuk berusaha saling memahami dan menghargai dengan dialog. Namun yang terjadi di lapangan adalah serial monolog oleh tokoh agama yang sangat tergantung proyek Depag. Barangkali memang inilah penyakit yang sudah akut dari para pejabat birokrasi kita baik birokrat kekuasaan maupun birokrat agama. Mereka benar-benar menampilkan diri sebagai "birokrat agung agama" yang merasa harus disanjung-sanjung, dihormati, dilayani, serta menghabiskan anggaran negara. Birokrat agung agama merasa paling bertanggung jawab atas keimanan seseorang, sehingga dapat memutuskan seseorang beriman atau kufr. Sungguh, agamaagama tidak lagi menjadi bagian dari pembebasan umatnya, namun malahan menjadi penabur benih-benih pertentangan di antara mereka penganut agama yang berbedabeda. Dialog semacam ini jelas-jelas kegagalan pertama yang dilakukan oleh birokrat agung agama. 
Disebabkan kondisi masyarakat agama seperti itu, maka tidak ayal lagi ketika awal tahun 1990-an muncul pelbagai aktivitas dialog antariman, yang bisa dianggap benarbenar menjadi cikal-bakal gerakan interfaith, dimana banyak orang berbeda-beda agama formalnya mampu duduk bersama, membahas másalàh-masalah bersama sekitar teologi, doktrin agama, praksis agama-agama dengan segala ketèrbukaani, kejujưran, kesetaraan, tanpa disertai ingin meñang sendiri dengan tujuan menjatuhkan agama lain, mencela dan menjelekkan agama lain, masyarakat agama pun terus mencibir, bahkan mengkafirkan.Kafir-mengkafirkan menjadi jargon paling santer bagi akitivis dialog antariman, sebuah istilah lama yang selalu direproduksi-terus-menerus dalam khazanàih hubungan antaragama.

Sebagai seorang muslim, dimana pernah bekerja di lembaga yang aktivitasnya memang banyak dalam hal dialog antariman, saya sangat sering dituduh óleh sesama muslim sebagai seorang "pengkhianat"yang hendak-menjual keimanan dengan harga yang murahan. Keislaman saya dipertanyakan kemurnian dan kekuatannya, karena terlampau sering keluar-masuk gèreja, pura, vihara dan kelompok kepercayaan lainnya. Gereja, pura, vihara dan tempat-tempat ibadah agama lain dianggap sebagai tempat yang bukan saja tidak layak untuk didatangi, namun mendekati saja najis hukumnya. Oleh sebab itu, siapa saja kaum muslim yang berani datang ke tempat-tempat ibadah agama lain tidak ubahnya dengan seorang kufur, karena mereka di luar Islam merupakan kaumkafirin.

Dari kalangan muslim saya dituduh hendak menjual Islam dengan harga murahan, kafir dan tidak jelas keislamanannya. Sementara di luar umat Islam menuduh bahwa saya adalah seorang muslim yang disusupkan ke gereja-gereja, khususnya, dan tempattempat ibadah agama lain untuk mengamati, melihat dan mempelajari kelemahan dan kekurangan mereka untuk dicari-cari dan disampaikăn këlemahannya. Pendek kata, saya dituduh sebagai agen dakwah islamisasi di kalangan kristiani. Sedangkan dari kalangan Islam, dituduh sebagai orientalis Melayu-Jawa, sebuah istilah yang memiliki konotasi negatif atas pengkaji agama-agama khususnya Iș̣am di Indonesia.

Tuduhan di atas saya terima dengan lapang hati, tidak ada perasaan was-was apalagi keinginan menyerang balik. Saya berpikir itulah sebagai akibat dari kuatnya dominasi negara atas agama-agama, sehingga setiap orang beragama pantas dicurigai dan bila perlu dituduh sebagai pengkhianat, malah provokator dalam arti negatif. Ini jelas akibat yang paling riil dari cara keberagamaan kita yang terlalu tunduk pada kekuasaan negara dan kepalan para guru moral, kiai, pendeta,pastor maupun bhiku. Umat tidak ada pilihan atas keberagamaannya, kecuali menurut atas tafsir agama yang dilakukan elitenya.

Setelah tuduhan-tuduhan yang sebenarnya tidak berdasar tersebut mereda, aktivitas dialog antariman terus berlangsung, dan saya ternyata tetap menjadi seorang muslim, dalam arti tidak seperti dikhawatirkan para penuduh bahwa saya akan melakukan 
konversi agama, saya pun tidak pernah surut mengikuti pertemuan-pertemuan yang bersifat antaragama, dari kalangan intelektual maupun grass root. Di sinilah kemudian saya mendapatkan kenyataan masalah yang membutuhkan perhatian serius oleh aktivis dialog antariman di tanah air, bukan hanya kaum tua maupun elite agama, tetapi juga kaum muda dan para penggiat yang enggan disebut sebagai pengikut agama tertentu, tetapi lebih memilih moralitas agama.

Masalah tersebut adalah, jika dialog antariman digelar terutama di level elite atau menengah ke atas, di universitas-universitas, pusat studi, lembaga swadaya masyarakat, dan tempat-tempat lainnya kurang secara serius dan detail membahas masalah-masalah konkret yang dihadapi umat beriman. Bahkan, ada kesan masalahmasalah konkret dihindari dengan alasan untuk meminimalisir terjadinya perdebatan yang panjang dan mengarah pada klaim-klaim kebenaran agama tertentu. Perbedaan dasardasar teologis jarang dibicarakan secara detail, dengan alasan lebih baik membasa masalah-masalah non teologis yang mungkin diselesaikan bersama. Aktivitas dialog antariman lebih cenderung membahas persamaan-persamaan yang ada dalam agamaagama, ketimbang perbedaan-perbedaan yang memang nyata adanya dalam hal teologi.

Oleh sebab itulah, masalah teologi dialog, teologi toleran, teologi pluralis, dan teologi inklusifyang banyak digagas memang masih menyimpan masalah mendasar yakni masalah teologi itu sendiri. Hemat saya, aktivitas dialog antariman harus berani masuk pada wilayah yang dianggap paling sakral dari masing-masing umat beragama, yakni wilayah teologi untuk kemudian masuk pada masalah-masalah riil dari hubungan antaragama. Jika masalah teologi tidak selesai dibahas, saya menduga jalannya dialog antariman hanya akan menjadi intellectual exercise para aktivis dialog antariman, tetapi problema antaragama terus saja menganga di depannya.

Masalah lain ketika dialog antariman digelar adalah, adanya ketegangan batin. Hal ini saya kira karena selama ini saya sendiri selama bertahun-tahun di sekolah-sekolah baik dari SD sampai SMU, bahkan Perguruan Tinggi tidak pernah diberikan kebebasan untuk mengekspresikan dan mengaktualisasikan keimanan sebagai seorang muslim di tengah pluralisme agama. Sebagai seorang muslim saya sudah terbiasa sebelumnya diberi pandangan bahwa agama lain adalah salah, bahkan musuh dan agama setan oleh sebab itu tidak bisa diajak kerjasama. Bila perlu malah memerangi agama di luar agama kita sebagai muslim.

Dengan latar belakang kondisi psikis semacam itu maka saya merasa wajar ketika proses dialog antariman dilaksanakan banyak halangan. Saya merasa banyak tekakan beban psikologis yang harus dipikul, sekalipun ada hal positif yang saya dapatkan yakni terjadinya "gugatan-gugatan" kepercayaan dan pemahaman keagamaan (keislaman) selama ini. Pemahaman dan keyakinan agama yang selama ini saya miliki mendapatkan tantangan riil, bahwa di sekitar kita ada komunitas lain yang sama-sama memiliki kepercayaan dan pemahaman tentang agama, sebagaimana kita miliki. Pendek kata, 
keyakinan dan pemahaman saya menjadi terguncang dan tergugat oleh aktivitas dialog yang dilakukan secara terbuka, jujur dan sering.

Namun demikian, sekalipun saya merasa tergugat keyakinan dan pemahaman keagamaannya (keislamannya), saya malah semakin yakin bahwa seorang beriman kepada Tuhan akan semakin menemukan identitas dan jati dirinya ketika tidak segan-segan untuk bertukar pikiran, bertukar pengalaman, dan berdebat tentang pemahaman keagamaan yang dimiliki. Di mana dengan seluruh rangkaian diskusi yang berlangsung semakin memberikan keyakinan bahwa keislaman saya harus dipertahankan, dan perdalam dengan terus mempelajari agama sendiri dan juga memahami agama orang lain yang berbedabeda itu. Pendek kata, memahami dan berdebat dengan orang yang beragama lain dengan diri kita tidak pernah menjadikan diri saya berubah pikiran untuk melakukan konversi agama, apalagi melakukan "pengimanan" atas orang yang berbeda dengan kita, malah semakin memperkuat keyakinan akan agama masing-masing dengan wawasan baru.

Bergolak, berontak, mempertanyakan kembali pemahaman keislaman yang saya anut selama ini memang menjadi bagian tak terpisahkan ketika aktivitas intensitas dialog antariman berlangsung. Namun, kejadian-kejadian dalam dialog antariman yang berlangsung terbuka, jujur dan tanpa ada perasaan kalah-menang, superior-inferior memberikan kekayaan tersendiri dalam saya menjalani keislaman selama ini. Saya tidak pernah merasa keislaman saya tergerus karena sering bertemu, bergaul, membahas kitab suci agama lain, malahan membuat saya semakin meyakini bahwa itulah janji Tuhan menciptakan aneka ragam umat beragama supaya rukun, saling belajar dan menghargai.

\section{Problem Dialog Antariman}

Aktivitas dialog antariman merupakan kegiatan yang secara pribadi sangat berarti dalam konteks pluralitas agama. Tanpa persiapan kematangan, kelapangan hati maks aktivitas dialog antariman hanya akan berbuah hujatan-hujatan, bukan sebuah diskusi yang produktif. Dengan begitu, maka dialog antariman membutuhkan persiapan yang cukup memadai, bukan dalam arti penguasaan materi semata, namun persiapan untuk menemukan perbedaan-perbedaan juga persamaan-persamaan yang ada pada tiap-tiap agama. Bahkan, kesiapan menghadapi perbedaan inilah yang sebenarnya lebih penting, selain persiapan-persiapan lainnya.

Mengingat hal tersebut, dalam dialog antariman saya sendiri mengalami bahwa dialog antariman, sebenarnya bisa dikategorikan menjadi dua; yaitu dialog tekstualnormatif dan dialog realitas-dialog praksis.

Pertama, dialog normatif-tekstual merupakan dialog antariman yang mendasarkan pembahasannya pada kitab suci, doktrin-doktrin dan noktah-noktah agama-agama yang dipercaya oleh masing-masing umat agama sebagai panduan kehidupan. Dialog tekstualnormatif mengacu pada kerangka dan dalil-dalil yang telah disebutkan dalam "buku suci" tersebut. Yang dikemukakan dalam dialog tekstual-normatifadalah dalil-dalil pembenar 
yang menyatakan bahwa agama-agama adalah baik. Agama-agama tidak mengajarkan kerusuhan, agama-agama tidak mengajarkan perusakan lingkungan, agama-agama tidak mengajarkan penipuan, penindasan dan sebagainya. Pendek kata, dialog tekstual-normatif merupakan upaya pencarian justifikasi atas kebaikan-kebaikan dari agama-agama.

Dialog normatif-tekstual ini sering disebuat sebagai dialog "discursive dialogue", bukan debat atau unveling dialogue. Sebuah dialog yang lebih mendahulukan dialektik, mendengar orang yang berbeda pandangan, sikap dan cara beragama atau berteologinya. Discursive dialogue merupakan model dialog yang akan memberi porsi pengharagaan atas perbedaan dan menhormati cara-cara beragama yang bersifat personal. ${ }^{4}$

Dialog pada tataran ini memang ideal, dalam arti mengemukakan dasar-dasar normatif dari masing-masing umat beragama untuk bertegur sapa, bekerjasama, dan saling membantu. Idealisasi tekstual dari kitab suci dipercaya dan diagungkan oleh masing-masing penganut agama. Namun demikian, dialog tekstual-normatif seperti ini memiliki kelemahan ketika pada kenyataannya banyak dari orang beragama berbuat crutal, makar dan berada di luar kerangka normatif. Dengan melihat kondisi riil seperti ini, biasanya umat beragama aktivis dialog akan mengatakan bahwa kerusakan, pembunuhan, kecurangan, pencurian, korupsi itu dilakukan oleh mereka yang tidak beriman, dan tidak memahami kitab suci. Kita tidak bisa menyalahkan agama, tetapi oknum umat beragama yang salah.

Oknum umat beragama inilah yang tidak menghayati ajaran kitab suci agamanya, bahkan menjadikan agamanya tercoreng karena ulahnya. Orang beriman tidak setuju dengan segala bentuk angkara murka, kejahatan dan manipulasi yang dilakukan oleh personal-personal penganut agama, bahkan kelompok sekalipun. Orang beriman seakanakan steril dari kenyataan yang dilihatnya dalam dunia nyata. Kaum beriman berani menuduh bahwa para pelaku kejahatan adalah para perusak agama, bukan penganut yang baik dalam mensyiarkan agamanya.

Dari sini bisa dipahami jika dialog antariman yang bersifat tekstual-normatiflebih banyak menjadi justifikasi atas kaum beriman, dan agak menutup mata atas realitas yang terdapat dalam alam nyata. Para penganut dialog agama tekstual-normatif tidak berusaha melakukan kritik, apalagi "gugatan" atas pemahaman agamanya, bagaimana sebuah agama yang doktrinnya demikian suci dan baik menjadikan umatnya bertindak diluar kaidahkaidah kitab suci.

Inilah yang saya kira umat beriman berada pada perspektif dan jiwa beragama yang terbelah (split religious personality). Kaum beriman memiliki dua sikap sekaligus dalam berdialog. Satu sisi membenarkan dalil-dalil agama, tetapi pada saat yang sama tidak mau mengakui bahwa banyak dari orang beragama berlaku sangat berbeda jauh dari dalil-dalil yang dikemukakan dalam dialog. Dialog tekstual-normatifhanya indah

${ }^{4}$ Sharpe, "The Goals of Inter-Religious Dialogue," hal. 82 
didialogkan, namun sangat sulit dan berbeda dengan dunia kenyataan, dimana umat beragama memikiki keinginan-keinginan dan motivasi tertentu yang hanya diketahui oleh diri mereka masing-masing. Orang lain hanya bisa menebak-nebak apa isi kepalanya, isi hatinya, tetapi tidak bisa secara pasti mengetahuinya.

Ilustrasi tentang hal ini misalnya, dapat ditemukan pada adanya kecenderungan afiliasi keagamaan yang terjadi pada pasię di Rumah Sakit Sutton di Inggris pasca Perang Dunia II. Dimana pasien di sana banyak menganut aliran Methodis, Roman Catholics, Jews, Salvatory Army, dan Church England. Di samping juga terjadi kontradiski-kontradiksi antara kepemelukan dengan kebiasaan sehari-hari mereka. Mereka dalam keseharinnya ternyata hidup glamour, free sex, dan pemabuk berat. ${ }^{5}$

Kedua, dialog realitas-dialog praksis. Ini merupakan aktivitas dialog yang lebih menekankan pada adanya pemihakan yang konkret pada kaum dhuafa, kaum tertindas oleh kekuasaan maupun oleh kultur. Dialog realitas-dialog praksis adalah aktivitas yang mendasarkan pada kenyataan-kenyataan riil di lapangan yang diangkat kepermukaan. Dialog di sini tidak secara khusus berdasarkan pada kebenaran-kebenaran kitab suci atau doktrin-doktrin agama, namun "menyapa" realitas dengan keyakinan bahwa itulah masyarakat yang harus diselamatkan, disapa dan dibantu. Dialog model ini sering pula disebut sebagai human dialogue, sebuah dialog yang berkarakter eksistensialis dan tidak mengedepankan sikap apriori atas fenomena keagamaan. Di samping itu, human dialogue merupakan model dialog yang secara periodik melakukan interpretasi-interpretasi terminologi teologis berhadapan dengan problem-problem sosial, dan kapitalis seperti ketidakadilan. $^{6}$

Aktivitas dialog praksis adalah turun langsung ke lokasi dimana kaum papa, kaum terhina dan dina berada. Mereka kita entaskan baik melalui kemampuan material maupun kekuatan spiritual. Kekuatan material misalnya mereka dibantu dengan makanan pokok jika memang mereka lemah dalam hal ini. Kita bantu spiritual jika mereka mengalami depresi dan kurang percaya diri. Pendampingan atas mereka menjadi kata kunci yang tidak bisa dilewatkan. Kaum dhuafa tidak dicarikan dasar-dasar legitimasinya untuk dibantu atau diberantas dalam arti diciduk, tetapi mereka dengan semangat religius disapa agar mereka "selamat".

Dialog realitas-dialog praksis adalah bentuk konkret dari aktivitas kaum beriman kepada Tuhan. Bukti keimanannya adalah "menyapa kaum dhuafa" tanpa pandang bulu. Menyapa tanpa melihat jenis kelamin, etnis, suku dan jabatan. Siapa saja yang membutuhkan persapaan, maka disapa tanpa tendensi religius bahwa nanti-mereka akan melakukan konversi agama atau mereka akan mengatakan bahwa kita ini orang baik. Kita menyapa mereka karena terpanggil untuk jalan kemanusiaan. Kita menyapa mereka

${ }^{5}$ Michael Argyle dan Benjamin Bait Hallahmin, 1975, The Social Psychology of Religion, London: Routlege dan Kegan Paul, hal. 131-135.

${ }^{6}$ Eric J. Sharpe, "The Goals of Inter-Religious Dialogue," hal. 83 
karena dorongan keimanan sejati yang tidak mengharap "imbalan" pujian dari siapa saja. Dapat atau tidak dapat pujian menyapa kaum dhuafa adalah kewajiban.

Selain dari dua kategori sifat dialog di atas, sebenarnya aktivitas dialog antariman akan berlangsung ketika para peserta dialog sekurang-kurangnya memiliki tiga persyaratan; yakni dengan terbuka, setara dan tulus. Dialog dalam konteks ini bias dikatakan terbebas dari kepentingan-kepentingan (interests) politik atau teologi dominatif, kecuali teologi yang memihak pada kemanusiaan.

Dialog antariman akan berlangsung ketika setiap aktivitas dialog dikerjakan dengan sungguh-sungguh dalam ruang keterbukaan, tidak ada niat-niat menyembunyikan apa-apa yang menjadi kelemahan dan kekuatan dari masing-masing agama. Dialog harus berjalan dengan terbuka, tidak saling menghujat, saling menuduh atau saling menyembunyikan agenda-agenda di belakangnya.

Dialog antariman harus pula berjalan dengan setara. Dialog tidak akan berlangsung dengan memadai ketika antar peserta dialog terjadi gap. Ada posisi superior-inferior. itau ada kesan satu yang benar, sementara yang lain salah. Kedudukan dalam dialog harus setara, seimbang tidak ada paksaan, atau perasaan terpaksa. Dialog antariman harus berlangsung senetral mungkin sehingga tidak ada rasa ewuh pakewuh yang hanya akan meninggalkan lazy tolerance, sebuah sikap toleran standar ganda.

Dialog antariman juga harus berlangsung dengan ketulusan sejati. Ketulusan merupakan suasana batin seseorang yang tidak ada dalam jiwanya berharap imbalanimbalan atas apa yang dikerjakan. Bahkan, ketulusan merupakan pilar utama ketika seseorang hendak beraktivitas. Tanpa ketulusan maka kita akan menemukan keputusasaan ketika sesuatu yang kita kerjakan mengalami kegagalan. Hanya dengan ketulusan inilah aktivitas dialog antariman akan menemukan fungsinya.

Dialog antariman harus berjalan di atas fondasi saling memahami, saling menghormati perbedaan yang ada pada masing-masing agama, bukan mencari-cari kekurangan, kelemahan dan bermaksud menjatuhkan mitra dialog. Dialog antariman karena itu harus dikemas dengan menggunakan perspektif nurani yang lapang,jujur dan tidak berpretensi menyelesaikan masalah antaragama, tetapi mengurai benang kusut problem agama-agama. Ini yang paling penting.

Dua problem dialog antariman di atas sebenarnya masih diikuti problem yang sering saya temukan di lapangan, ketika aktivitas dialog antariman berlangsung di masyarakat, baik masyarakat akademik, maupun masyarakat awam (rakyat kebanyakan), yang seringkali "menjadi objek dialog" ahli-ahli agama. Dalam kapasitasnya dialog antariman untuk membangun tumbuhnya keberagamaan inklusif, khususnya di kelompok Islam ada beberapa problem, antara lain:

Pertama, segmentasi gerakan keagamaan dalam Islam yang sangat kentara, seperti munculnya kelompok fundamentalis-militan, moderat dan liberal. Gerakan Islam fundamentalis-militan hemat saya belum bisa menempatkan realitas pluralisme agama di 
negeri ini sebagai sesuatu yang taken for granted, sehingga jika mereka harus mengakui pluralitas agama ini, maka dengan segala argumentasi yang dikemukakan akan mengatakan bahwa sekurang-kurangnya pluralitas agama yang diakui Islam hanyalah ketika Nabi Muhammad belum mendapatkan wahyu terakhir, yang dipahami sebagai doktrin kesempurnaan Islam sebagai agama, sehingga agama-agama selain Islam adalah tidak lengkap, tidak memiliki kebenaran mutlak, karena itu agama di luar Islam adalah agama yang "salah", bahkan agama setan.

Pluralisme agama hanya untuk umat Yahudi, Nasrani dan Shabiin yang beriman kepada Tuhan, sebelum Muhammad datang menjadi nabi. Ketika Muhammad sudah datang sebagai nabi dan ketiga pemeluk agama tersebut tidak lagi beriman, maka pluralisme agama sudah dihapus oleh al-Quran dan Islam.

Kelompok fundamentalis-militan ini memang bukan hanya milik Islam, tetapi ada pada hampir tiap-tiap agama, termasuk Yahudi, Kristen, Hindu, dan Budha. Bagaimana klaim di antara mereka akan kebenaran agamanya yang mutlak, sehingga mereka menganggap jika ada kelompok agama yang memakai simbol-simbol dari agamanya dianggap sebagai sebuah pelecehan atau "manipulasi" atas agama yang bertujuan untuk meraih kepentingan-kepentingan jangka pendek, seperti kepentingan ekonomi dan politik. Apa yang pernah menimpa penganut Hindu Bali dengan menganggap kaum Kristiani melakukan manipulasi agama Hindu karena menggunakan nama-nama sekolah dan rumah sakit dengan simbol Hindu merupakan gejala fundamentalisme-militansi agama yang selalu hadir di tengah masyarakat agama.

Hal yang sama juga teradi, ketika novelis Dewi Supernova(Dee) memakai sampul bukunya yang baru dengan lambang Hindu, kemudian digugat sebagai sebuah pelecehan, karena kita tahu bahwa Dee adalah seorang Kristen dan bukunya hendak dijual ke pasaran yang pembelinya bukan hanya orang Hindu atau Kristen saja. Demikian juga, ada kelompok Kristiani yang masih berpegangan bahwa di luar gereja tidak ada keselamatan, sebab orang yang selamat harus menjadi "umat Yesus", selain itu tidak bisa selamat. Semua ini tanda-tanda ada kelompok fundamentalis-militan dalam agama-agama di negeri ini. Kelompok ini sering disebut sebagai kelompok eksklusif, intoleran.

Selain kelompok fundamentalis-militan, ada kelompok moderat yang menganggap bahwa pluralisme agama adalah fakta sosial yang tidak perlu diributkan, apalagi menjadi bahan pertengkaran. Pluralisme agama biarlah seperti adanya, sebagaimana Tuhan menciptakan. Tidak perlu khawatir dengan pluralisme agama, karena memang Tuhan berkehendak menjadi umat yang beragam, tidak seragam satu dengan yang lain.

Pandangan kelompok ini biasanya menyataka bahwa pluralisme agama akan menjadi problem umat beragama ketika dibawa pada wilayah ekonomi dan politik, sebab dua wilayah inilah yang kemudian menjadikan umat beragama saling berebut pengaruh untuk mendapatkan akses ekonomi dan politik, dengan cara "merekrut sebanyak mungkin jamaah". Hanya saja, pandangan mereka yang moderat ini seringkali 
dimasukkan dalam kelompok liberal, sehingga dalam pandangan kaum fundamentalis kaum moderat ini tetap dianggap sebagai kelompok yang bertujuan merelatifkan keimanan seseorang atas agamanya. Kelompok ini sering disebut sebagai kelompok inklusif-toleran dan dialogis.

Sementara itu, kelompok liberal, merupakan kelompok kecil sebenarnya yang ada dalam tubuh agama-agama, termasuk dalam tubuh Islam. Kaum liberal dalam Islam seringkali dituduh sebagai "agen zionis", agen Barat-Amerika dan yang paling sempit adalah bahwa kelompok liberal adalah agen funding. Kelompok liberal ini adalah kelompok yang dianggap oleh kelompok fundamentalis sebagai kelompok "perusak akidah Islam" dengan gagasan-gagasannya tentang pluralisme, kesetaraan gender, Hak Asasi Manusia (HAM), demokrasi dan hubungan antaragama.

Kelompok liberal, sekalipun hanya kecil, dan berada di unit-unit tertentu seperti perguruan tinggi, lembaga swadaya masyarakat (LSM), dan aktivis politik memang berpengaruh cukup besar dalam mengkampanyekan isu-isu yang menjadi perhatiannya. Kelompok ini memiliki keahlian yang memadai dalam mengemas isu untuk diwacanakan ke publik sehingga publik dapat menikmatinya secara kontinuitas, dengan cara yang modern dan profesional, misalnya dengan menulis di koran, di jurnal, menulis buku, dan melalui internet, selain cara-cara konvensional diskusi, seminar dan workshop.

Kelompok liberal ini, dalam pandangan saya memang acapkali berbeda dalam melihat agama Islam dengan kelompok fundamentalis, namun seperti tadi agak-agak mirip dengan kaum moderat. Yang paling terang, perbedaannya dengan kaum fundamentalis adalah kelompok liberal mencoba menghadirkan Islam sebagai sebuah fakta sosial, sehingga selalu dinamis, tidakmandeg, dan melihat Islam harus membutuhkan tafsir-tafsir atas kitab sucinya, dengan membaca kitab secara kritis, menafsirkan ulang apa yang ada dalam kitab suci. Kelompok ini biasanya diidentikan dengan kelompok penganut teologi dialogis-pluralis.

Kedua, munculnya tiga kelompok besar dalam Islam seperti itu, hemat saya terjadi karena adanya kendala besar dalam proses pemahaman keagamaan yang hanya memunculkan pemahaman yang bercorak teologis di satu pihak, dan pemahaman praksis di lain pihak.

Pemahaman teologis ini seringkali muncul dari kalangan akademisi, atau aktivis dialog antariman yang tidak melakukan aktivitas "penggalangan massa" di level jamaah atau umat. Pemahaman teologis atas doktrin-doktrin keislaman terjadi akibat pengkajian yang sifatnya lebih teoritik, sehingga melihat Islam adalah sebuah fenomena teologis, yang berbeda dengan fenomena praksis. Sebagai fenomena teologis, maka Islam memang berbeda dengan fenomena praksis sosial. Antara teologi Islam dengan teologi di luar Islam memang tidak bisa diperbandingkan, hanya bisa dicarikan titik temunya, dengan apa yang dinamakan kalimatun sawâ, titik temu agama-agama, namun tidak bisa menilai agama lain dengan kacamata Islam. 
Sementara itu, pemahaman praksis muncul karena Islam dianggap sebagai sebuah wilayah yang terkait dengan masalah-masalah sosial, politik, ekonomi dan budaya, terutama oleh para juru dakwah dalam Islam yang memiliki keyakinan untuk bertugas menyebarkan agama Islam ke tengah masyarakat yang belum Islam, sekalipun sudah beragama lain. Sebab dalam pandangan kaum praksis, agama di luar Islam adalah agama yang tidak sesuai dengan kehendak Tuhan, agama yang tidak menyelamatkan umat manusia.

Dua cara pandang inilah yang tidak bisa bertemu, sehingga setiap ada dialog antariman yang menghadirkan dua kelompok ini selalu terjadi silang pendapat yang bersebrangan, bahkan cenderung saling menyalahkan antara satu dengan yang lain, atau sekurang-kurangnya salingmenghilangkan keunikan masing-masing. Corakteologis bertahan pada pandangannya, sementara corak praksis juga demikian, tidak bisa beranjak pada wilayah teologis, bahkan cenderung dihindari. Yang menarik, kelompok corak teologis biasanya berani melakukan kritik atas ajaran teologisnya untuk dikonfrontasikan dengan realitas sosial yang terjadi dan terus berkembang.

Ketiga, terjadinya kecurigaan atas aktivitas dialog antariman. Kecurigaan ini hemat saya muncul disebabkan kisah-kisah masa lalu yang seram dalam tradisi agamaagama misionaris, diteruskan dengan adanya informasi-informasi yang berkembang di masyarakat bahwa agama Islam itu agama yang hendak menyelamatkan agama Kristen, demikian juga agama Kristen hendak mengkristenkan orang Islam. Apa yang disebut misionaris Islam dan misionaris Kristen dalam perebutan umat agama terus berlangsung.

Bahkan, yang paling sering terdengar ketika ada aktivitas dialog antariman adalah adanya informasi proses penghamilan dari pemuda-pemuda Kristen atas gadis muslimah sebagai strategi kristenisasi. Sebaliknya, dari kalangan Kristen mengatakan terjadi islamisasi dengan cara pemuda Islam mencari pacar gadis kristiani. Dua-duanya terus bertahan pada pandangannya yang berdasarkan satu dua peristiwa di masyarakat, namun seakan-akan menjadi bukti otentik bahwa gereja merestui proses penghamilan di luar nikah gadis muslimah. Demikian juga seakan-akan guru ngaji, ustad, kiai, dan juru dakwah membuat strategi “memacari”' gadis kristiani untuk dijadikan istri kelak, sehingga gadis kristen tadi masuk Islam. Dua-duanya bertahan pada kasus yang ditemukan di tengah masyarakat.

Dengan adanya kecurigaan tersebut, maka tumbuhlah distrust dalam aktivitas dialog antariman, sebab dibelakangnya senantiasa disertai prasangka-prasangka bahwa dialog antariman hanyalah pemanis semata-mata, hanya basa-basi, tidak tulus dan disertai agenda-agenda tersembunyi di belakangnya. Sebab itu, apa yang saya kemukakan di awal bahwa aktivis dialog antariman akan dituduh antek Kristen, antek Islam, antek Zionis, antek komunis, antek rezim dan antek funding terus berlangsung.

Keempat, minimnya keterlibatan perempuan dalam gerakan antariman baik pada level nasional atau level lokal. Sepanjang pengalaman saya bergelut dengan aktivitas 
dialog antariman, sangat minim keterlibatan kaum perempuan dalam aktivitas ini. Saya menjadi bertanya-tanya apa sebabnya perempuan sedikit yang terlibat dalam gerakan dialog antariman, beda dengan aktivitas perempuan dalam isu kesetaraan jender atau isu feminisme, sekalipun keterlibatan dalam isu kesetaraan jender dan feminisme juga sedikit, jika melihat kuantitas perempuan Indonesia secara keseluruhan.

Namun, pertanyaan tersebut segera terjawab ketika beberapa fakta sosial membuktikan bahwa, dalam Islam khususnya, pemahaman bahwa perempuan lebih baik menjadi "teman belakang" atau "teman suami" lebih kuat ketimbang pemahaman bahwa antara laki-laki perempuan memiliki peran dan fungsi yang sama. Perempuan lebih baik menjadi pengasuh anak, lebih mulia menjaga rumah, bekerja di rumah, bukan pada wilayah-wilayah yang hadir di sana kebanyakan kaum lelaki, sebab perempuan akan gampang menimbulkan syahwat laki-laki dan menggoda laki-laki, maka tinggal di rumah, mendidik anak dalam arti menyusui, memandikan, dan mengantar sekolah adalah lebih mulia dan berjihad, sebagai ibu yang sholih, ketimbang harus aktif dalam kegiatan-kegiatan di luar rumah.

Pandangan seperti ini memang belakangan banyak digugat oleh para aktivis perempuan sebagai paham yang memarjinalkan perempuan, mendomestikasikan perempuan dan paham yang merupakan "jebakan-jebakan paternalistik", yang timbul akibat adanya tafsir agama yang misoginis, bukan berperspektifgender. Namun begitu, sebagian perempuan Islam, tampak lebih dapat menerima pekerjaan perempuan sebagai istri yang dianggap sholih oleh agamanya ketimbang dianggap membangkang terhadap agamanya, atau sekurang-kurangnya dianggap membangkang terhadap suaminya. Banyakjuga perempuan yang "menerima" fatwa suaminya untuk tidak terlibat dalam aktivitas di luar demi menjaga anaknya, merawat dan memandikan, selain mengantar ke sekolah dan pergi ke pasar untuk belanja.

Memang sejak tahun 1990-an telah mulai terlihat keterlibatan perempuan dalam aktivitas di wilayah publik, seperti pertemuan-pertemuan sesama perempuan untuk membicarakan masalah mereka, seperti masalah mereka dengan agamanya, baik Islam, Kristen, Hindu, Budha maupun Konghucu, seperti pernah dikerjakan oleh Kelompok Perempuan Sadar Yogyakarta (KPS), tahun 1998, ketika mengumpulkan aktivis-aktivis perempuan untuk melakukan sharing bersama antarperempuan berbeda-beda agama. Kemudian Lingkaran Pendidikan Alternatif(KAPAL) Perempuan, yang berdiri tahun 2001 dengan penggagasnya antara lain Neng Dara Afifah, Ciciek Farkha. Namun, tampaknya kegiatan semacam ini mengalami kemandegan di tengah jalan, tidak bisa kontinyu. Ada banyak persoalan di sana, misalnya, karena tidak dana yang digunakan untuk mengumpulkan banyak perempuan untuk hadir membahas masalah mereka sebagai masalah bersama antariman. Atau juga karena sulitnya mendapatkan perempuan aktivis yang mampu dengan baik melakukan refleksi tertulis atas pekerjaan yang selama ini mereka kerjakan. 
Belakangan, kira-kira akhir 1990-an, hingga 2004 ini saya kira aktivitas perempuan dalam wilayah publik semakin banyak, terutama dengan semakin banyaknya gerakan perempuan yang mengusung tema-tema kesetaraan jender, feminisme, dan anti diskriminasi terhadap perempuan. Tetapi, lagi-lagi saya merasa keterlibatan perempuan muslim dalam isu-isu antariman tidak sebanding dengan masalah yang mereka hadapi di tengah masyarakat saat ini. Perempuan muslim Indonesia memang dianggap lebih beruntung dibanding perempuan muslim di negeri-negeri seperti Arab Saudi,Afghanistan, Al-Jazair, Sudan dan Mesir. Tetapi tidak berarti perempuan muslim Indonesia sudah bebas dari jebakan-jebakan teologis yang tidak emansipatoris dan liberatif atas perempuan.

Oleh sebab itu, kurangnya perempuan dalam aktivitas gerakan antariman hemat saya memang karena "ruang untuk perempuan" masih sempit, ditambah lagi adanya problem inemal perempuan yang acapkali "menerima apa adanya" dengan kondisi yang sekarang telah menimpanya sebagai sebuah takdir, atau sebagai sebuah keniscayaan hidup yang harus dijalani secara iklhas, sebab dengan ikhlas Tuhan akan memberikan karunia untuk mendapatkan kehidupan yang lebih mulia kelak setelah meninggal dunia nanti. Perempuan yang ikhlas akan mendapatkan sorga yang paling nikmat, paling mulia atas jasa-jasanya mendidik anak, memandikan, dan mengantarkan ke sekolah setiap pagi, serta jangan lupa "melayani suami" pada saat suami "meminta" dalamkondisi apapun, sebab ditakut-takuti dengan ancaman Tuhan dan malaikat akan melaknatnya hingga pagi hari. Ini mengerikan sekali buat kemajuan aktivitas perempuan dalam gerakan antariman.

\section{Keimanan Inklusif}

Dengan pelbagai persoalan yang menghadang agama-agama, termasuk Islam, seperti telah dikemukakan diatas, maka kita perlu mencari jalan baru dalam berislamsehingga Islam tidak sekedar menjadi justifikasi atas kekuasaan, atau apologi atas kebenaran dan keagungan ajarannya.

Kita melihat bagaimana agama-agama mendapatkan tantangan yang real dalam perjalanannya. Masalah korupsi, kolusi dan nepotisme yang dikenal dengan $\mathrm{KKN}$ di republik ini sungguh tidak bisa dibiarkan begitu saja. KKN yang telah menggurita menjadi penyakit paling kronis di nusantara ini, sebab KKN sudah dilakukan oleh mereka yang menyatakan diri sebagai umat beragama. Bahkan, KKN seakan-akan sudah menjadi karakter bangsa ini. KKN bagaikan kanker spiritualitas umat. Apa yang bisa dilakukan oleh organized religion dan religious organized, saya belum melihat secara riil. Bahkan, organized religion dan religious organized tampak tenang-tenang saja bagaikan tidak ada masalah serius dengan bangsa ini. Istilah organized religious dan religious organized, saya pinjam dari John Naisbitt dan Patricia Aburdene. ${ }^{7}$

7John Naisbitt dan Patricia A burdene, 1990, Megatrends 2000, Jakarta: Binarupa Aksara, hal. 258-259. 
Itulah problem agama yang serba formalis dan menjadikan ritual keagamaan sebagai basis utama seseorang diukur beriman atau tidak. Jika ukuran keimanan seseorang bukan pada rutinitas ritual simbolis keagamaan, barangkali kita tidak akan mendapatkan split personality religious yang menampakan adanya kontradiksi-kontradiksi antara nilai-nilai ajaran moral Islam dengan perilaku sehari-hari. Di sinilah, hemat saya dimensi spiritualitas harus menjadi lahan baru orang berislam. Dimensi spiritualitas tidak berarti seorang muslim meninggalkan praktek-praktek ritual-simbolik, tetapi bahkan spiritualissimbolis dijadikan pijakan awal untuk menuju keislaman yang lebih menjiwai. Istilah passing over coming back $^{8}$ dalam ber-Islam barangkali bisa dipertimbangkan, karena tidak berarti menghilangkan identitas keislaman ketika bergaul dan bertegur sapa dengan orang yang beragam agama. Dimensi spiritualitas menjadi penting dikemukakan sebab selama ini, pemahaman umum adalah, ketika spiritualitas maka tidak lagi melakukan aktivitas ritual-simbolik sebagai tahapan awal menapaki keislaman yang bisa dibilang lebih substansial. Spiritualitas agama-agama juga merupakan pertemuan dari agama¿gama yang dalam istilah Frithjof Schuon disebut dengan esoterisme, sedangkan formalisme agama disebut sebagai eksoterisme yang masing-masing agama berbedabeda. $^{9}$

Jika boleh disebut, sebenarnya problem keislaman selama ini disebabkan karena terjadinya tafsir yang amat rigid tentang teologi. Dimana teologi hanya dipahami sebagai masalah yang berkaitan dengan Tuhan, bukan berkaiatan dengan manusia, sehingga apapun yang telah dilakukan seorang muslim jika sudah rajin shalat maka dinilai pasti saleh secara sosial. Padahal kita ketahui, bahwa kesalehan individual seperti saya kemukakan di atas seringkali bertolak belakang dengan kesalehan sosial. Oleh sebab itulah, hemat saya kita harus mampu beranjak dari tafsir formalis teologi Ketuhanan menjadi teologi yang berpijak pada kemanusiaan. Teologi inilah yang saya sebut sebagai teologi antropologis.

Selain problem rigid atas tafsir teologis, keislaman kita juga amat sering terjebak pada keislaman yang bersifat historis. Seperti telah dikemukakan di atas, bahwa keislaman yang datang bukanlah keislaman yang imun dari dari konteks historis ketika itu, oleh sebab itu hemat saya perlu melakukan kontekstualisasi historis dan transendensi historis agar kita bisa keluar dari jebakan-jebakan sejarah yang mengakibatkan terpuruknya bangsa ini sebagai bangsa beradab menjadi tribal society.

Oleh karena itu, apapun alasannya hemat saya kita membutuhkan tafsir-tafsir baru atas dalil-dalil kitab suci. Posisi interpretasi para ulama terdahulu tidakkita jadikan berhala baru dalam berislam, tetapi kita tempatkan sebagai perbandingan antara situasi dahulu dengan situasi kontemporer. Bahkan bila perlu kita melakukan koreksi dan pembongkaran atas tafsir yang pernah dilakukan para mujtahid dahulu. Tafsir-tafsir baru

${ }^{8} \mathrm{John}$ S. Dunne, 1972, The Way of All the Earth, New York: Macmillan, hal. ix ${ }^{9}$ Frithjof Schuon, 1984, The Trancendent Unity of Religion, USA, hal. xii-xv 
akan dalil kitab suci buat saya tidak bisa ditawar-tawar lagi, sehingga Islam dengan dalildalilnya tidak menjadi barang recehan dan instant seperti entrostop, sanaflu, decolgen, mixagrip dan pelbagai macam obat-obatan yang bersifat instan dalam mengatasi suatu penyakit.

Mengatasi problem semacam itu, hemat saya tidak ada kata lain kita sebagai seorang beragama harus melakukan perjalanan spiritual yang lebih substansif, ketimbang beragama secara rigid ritual tetapi hampa spiritualitas. Spiritualitas beragama akan menemukan titik temu dengan agama-agama lain ketika bersentuhan langsung dengan problem-problem kemanusiaan, ketimbang masalah teologis. Masalah teologis sudahlah kita serahkan pada masing-masing agama, tak usah kita mengutak-atik paham teologi orang lain karena kecenderungannya adalah menempatkan teologi agama lain dengan perspektif teologi kita (Islam atau Kristen) maka jelas tidak akan bertemu.

Jika kita memang menghendaki dialog yang memadai tentang agama-agama, maka perspektif kita adalah perspektif yang meletakkan paham teologi pada tiap-tiap penganut, dan bahkan pada perspektif substansialis yang lebih mencerminkan spiritualitas agamaagama. Spiritualitas beragama inilah yang sebenarnya melampaui simbol-simbol agama, sehingga mampu menempatkan semua pemeluk agama sebagai bagian dari dirinya sendiri. Tidak menganggap orang di luar Islam sebagai enemy, atau sekurang-kurangnya sebagai orang yang harus diislamkan. Di situ pula sebenarnya letak penghargaan Islam atas realitas pluralisme agama. Islam tidak memaksakan agama. Dalam tafsir ini kita harus meletakkan dalil lakum dînukum waliyadîn adalah meletakkan agama-agama di luar Islam sama kedudukannya di hadapan agama kita sebagai agama untuk seluruh umat manusia.

Dengan cara melakukan reinventing masalah-masalah keislaman yang muncul, maka problem dialog antariman akan terminimalisir dengan mengangkat dimensi sosial dari agama-agama sehingga ketidakadilan jender, diskriminasi agama-agama atas agame lain, semangat parokialisme mulai terkikis. Jika masalah-masalah riil seperti telah dikemukakan diatas dapat didialogkan dengan terbuka, tanpa pretensi mampu diselesaikan semuanya, dan tanpa agenda tersembunyi dibelakangnya, maka civil religion yang didambakan oleh umat beragama akan mulai tampak bersinar, sekalipun belum terang benderang.

Masyarakat agama sipil yang didambakan sebenarnya merupakan bagian tak terpisahkan dari kehidupan keberagamaan yang mampu menghargai dan menghormati kepelbagaian. Perbedaan dalam keberagamaan bukan dianggap sebagai sebuah penghalang untuk melakukan dialog, saling sapa dan kerja sama. Oleh sebab itu, hemat saya keberagamaan inklusif bisa dikatakan sebagai model keberagamaan yang sungguhsungguh mengangkat harkat dan martabat kemanusiaan umat manusia, tanpa membedabedakan agama, suku, ras dan golongan. Keberagamaan seperti inilah yang sejatinya akan membawa kita pada model keberagamaan yang lebih toleran dan tidak membabi buta melihat perbedaan. 
Keimanan inklusif merupakan keimanan yang tidak standar ganda, meletakkan agamanya sendiri sebagai agama paling sempurna, paling mewadahi semuanya, paling benar, dan menyelamatkan, sementara agama orang lain ada keselamatan, ada kebenaran namun tidak lengkap dan malah cenderung menyimpang. Keimanan inklusif adalah keimanan yang menghargai ada keselamatan di luar agamanya. ${ }^{10}$ Inilah yang sesungguhnya menjadi bagian tugas para agamawan untuk membongkar paham-paham teologi umatnya menuju paham teologi yang inklusif. Tanpa ada kemauan membongkar paham teologi yang telah dianut selama ini, tentu kita akan sausah mendambakan adanya keberagamaan yang inklusif.

\section{E. Penutup}

Sudah lama kita mendambakan keberagamaan yang dapat menghormati dan menghargai perbedaan sebagaimana mestinya. Tidak ada saling paksa antarsesama pemeluk agama, apapun agamanya. Bahkan, kita sebagai pemeluk agama tradisi nonoteistik, agaknya perlu melakukan kritik dan koreksi atas keberagamaan kita, sehingga tidak menjadikan keberagamaan monoteistik sebagai keberagamaan yang hegemonic. Keberagamaan hegemonik adalah keberagamaan yang menganggap keberagamaan lain berada jauh di bawah standar keberagaman kita, dan perlu "diselamatkan".

Dalam kaitan dengan agama misionaris, maka yang harus pula dikerjakan adalah perlunya tafsir baru atas paradigma misi atau dakwah. Misi atau dakwah harus senantiasa ditafsir ulang sehingga mampu memunculkan paham dan paradigma teologi yang mampu merespon tantangan-tantangan riil kemanusiaan. Pemikiran teologikita harus sesuai dengan kondisi zaman yang terus berubah, masyarakat plural yang menjadi bagian dari kehidupan kita serta memberikan peluang kepada mereka yang keberimanannya berbeda dengan kita untuk meningkatkan derajat keimanannya secara terbuka. ${ }^{\text {I }}$

Pertanyaan untuk umat Islam dan umat agama lain, mungkinkah kita duduk bersama untuk membahas masalah-masalah riil kemanusiaan, tanpa disertai agendaagenda tersembunyi di belakangnya, tanpa prasangka dan perasaan superior atau inferior antar sesama umat beriman? Jawabannya terletak pada kita semua sebagai umat yang mengaku beriman pada Tuhan.

${ }^{10}$ Charles Kimball, 2003, Kala Agama Jadi Bencana, Bandung: Mizan, hal. 293-305.

"Barbara Zigmun Brown, Dialog Agama-Agama dalam Konteks Misionarisme baru, dalam Komaruddin Hidayat dan Ahmad Gaus, AF, 1998, Passing Over Melintasi Batas Agama, Jakarta: Gramedia, hal. 33 . 


\section{DAFTAR PUSTAKA}

Armstrong, Karen, 2001, Sejarah Tuhan, alih bahasa Zainul Am, Bandung: Mizan.

-.---, 2003, Perang Suci, alih bahasa Hikmat Darmawan, Jakarta: Serambi.

Argyle, Michael, dan Benjamin Bait Hallahmi, 1975, The Social Psychologyof Religion, London: Routlege dan Kegan Paul.

Durkheim, Emile, 1969, The Elementary Forms of the Religious Life, George Allen \&Unwin.

Dunne, John, S, 1972, The Way of All the Earth, New York: Macmillan.

Hidayat, Komaruddin dan Ahmad Gaus, AF, 1998, Passing Over Melintasi Batas Agama, Jakarta: Gramedia

Kimball, Charles, 2003, Kala Agama Jadi Bencana, alih bahasa Nurhadi, Bandung: Mizan.

Naisbitt, John \& Patricia Aburdenen, 1990, Megantrends 2000, Jakarta: Binarupa Aksara.

Schuon, Frithjof, 1984, The Trancendent Unity of Religions, USA.

Share, Eric J, The Goals Inter-Religious Dialogue, dalam John Hick, (ed), 1976, Truth and Dialogue, London: Sheldon Press. 